\title{
O Brasil sob Cardoso neoliberalismo e desenvolvimentismo
}

\author{
BRASILIOSALLUM JR
}

RESUMO: Este artigo tem três partes. Na primeira, faz-se o exame dos processos de conquista do poder de Estado que culminaram na eleição de FHC usando o conceito de hegemonia e a idéia de momento maquiaveliano, derivada de Pocock. Na segunda parte, mostra-se que o novo bloco político no poder, para além de sua orientação liberal e internacionalizante, polariza-se entre duas versões contrapostas de liberalismo, o fundamentalismo neoliberal e o liberal-desenvolvimentismo. Discute-se os efeitos socioeconômicos da adoção pelo governo do neoliberalismo como eixo de sua política macroeconômica. $\mathrm{Na}$ terceira parte, analisam-se as razões políticas que levaram a Presidência reiteradamente a essa escolha. A hipótese explicativa sugerida é de que a Presidência da República interpretou a manutenção do fundamentalismo neoliberal como um meio decisivo para assegurar o necessário controle sobre o sistema político. Sugere-se, ao final, que as mudanças macroeconômicas iniciadas em janeiro de 1999 dão as bases para uma reorientação liberaldesenvolvimentista do governo.

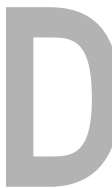

esde os anos 80, quase todos os países da América Latina vêm passando por profundos processos de transição política. Não se trata apenas de mudanças de regime político. Também tem se alterado a relação entre poder político, sociedade e mercado e a forma de inserção internacional das economias nacionais ${ }^{1}$. Entretanto, em cada país latino-americano, os ritmos e as formas particulares de transformação ocorridas nas várias dimensões têm sido muito diferentes.
UNITERMOS:

Estado, governo, crise política, transição política, hegemonia, politica econômica, desenvolvimento, neoliberalismo, Fernando Henrique Cardoso.

Professor do Departamento de Sociologia da FFLCH - USP 
No Brasil, é evidente que a mudança no regime político se deu mais rapidamente do que nas demais dimensões. É por isso que Fernando Henrique Cardoso, ainda antes de sua posse na Presidência da República, pode situar o seu governo entre duas dimensões/etapas da transição. Entre a transição político-institucional para a democracia, que se teria encerrado com a sua própria eleição ${ }^{2}$, e a transição para além da Era Vargas, que assume como programa de governo. Propunha-se, assim, sob as regras de uma democracia política consolidada, romper com certas articulações entre poder político, sociedade e economia remanescentes do período Getúlio Vargas.

Neste artigo examino em que direção foram transformadas as relações entre política e economia, ao longo do governo Fernando Henrique. Na primeira seção, procuro colocar em perspectiva sociológica as intenções enunciadas pelo presidente, mostrando que elas reafirmavam o rumo predominante no próprio processo de transformação histórica em curso. Logo depois, sublinho a maneira específica com que o governo Cardoso tentou superar o que denomina Era Vargas. Por último, sugiro algumas hipóteses para explicar politicamente a orientação da política econômica do governo FH.

Discuti este artigo com Gildo Marçal Brandão, Eduardo Kugelmas e Geraldo Gardenalli, a quem agradeço pelas críticas e sugestões.

\footnotetext{
${ }^{1}$ Manuel Garretón sublinha, com razão, que as transições políticas (de regime) vêm ocorrendo em meio a uma verdadeira crise da "matriz sóciopolítica” dos países latino-americanos (cf. Garretón, 1993).

${ }^{2}$ Nas palavras do Presidente eleito: "estas eleições (de outubro de 1994) colocam, a meu ver, um ponto final na transição. Depois de 16 anos de marchas e contramarchas, a 'abertura lenta e gradual' do expresidente Geisel parece finalmente chegar ao porto seguro de uma democracia consolidada" (Fernando Henrique Cardoso, dircurso ao Senado, 14/12/94).
}

\section{Transição Política, Moeda e Eleição}

A interseção entre política e economia foi uma questão chave no debate em torno da ascensão de Fernando Henrique ao poder, antes mesmo do início de seu governo. Sua própria eleição foi interpretada sob pontos de vista diametralmente opostos no que se refere às relações com a economia.

Já durante a campanha, duas interpretações principais competiram pelo entendimento do fenômeno eleitoral - uma voluntarista e outra hiperestruturalista. Conforme a primeira, Fernando Henrique teria concebido o Plano Real para eleger-se. Aqui não é relevante se o candidato foi identificado como ser benfazejo ou maléfico. O que importa é que sua vontade foi interpretada como capaz de dominar uma economia em desordem e, por consequiência, ganhar o favor popular. De acordo com a segunda interpretação, pelo contrário, "o Plano Real não teria sido concebido para eleger FHC mas, na ordem inversa, a candidatura FHC teria sido gestada pelas novas elites dominantes para viabilizar, no Brasil, a coalizão de poder capaz de dar sustentação de permanência ao programa de estabilização hegemônico" [no âmbito do capitalismo mundial](Fiori, 1995, p. 236). Esta interpretação cede "à tentação ou à obstinação de considerar Fernando Henrique Cardoso uma engrenagem decorativa na moenda da nova etapa do capitalismo mundializado"(Nobre \& Freire, 1998).

Convertendo Fernando Henrique em demiurgo ou, ao invés, em joguete de movimentos estruturais, essas vertentes explicativas opostas economizam analiticamente quer os processos sociais de construção e direcionamento da vontade política quer a própria política enquanto atividade de articulação da vontade coletiva.

De fato, a coligação eleitoral que articulou a candidatura Cardoso 
deu o acabamento final a um longo processo de construção social de um novo bloco hegemônico saído das entranhas da Era Vargas mas em oposição a ela. Vejamos isso com mais vagar.

AEra Vargas refere-se metaforicamente a um sistema de dominação enraizado na sociedade e na economia que se perpetuou por mais de meio século na vida brasileira. Começou a ser construído nos anos 30, atingiu o ápice na década de 1970 e desagregou-se paulatinamente a partir dos anos $80^{3}$.

Ao longo desse período, o Estado passou a constituir-se em núcleo organizador da sociedade brasileira e alavanca de construção do capitalismo industrial no país. Quer dizer, tornou-se um Estado de tipo desenvolvimentista. Nos últimos anos da década de 1970, entretanto, essa estrutura complexa de dominação começou a sofrer um processo lento e descontínuo de desgaste. A partir daí a capacidade de comando do velho Estado sobre a sociedade e a economia passa a ser severamente restringida, tanto pelas transformações econômicas internacionais, que marcam a transição do capitalismo mundial para sua forma transnacional, como pela emergência de movimentos e formas de organização autônoma dos segmentos sociais, principalmente dos subalternos. Numa palavra: transnacionalização do capitalismo e democratização da sociedade foram (e vêm sendo), sob várias modalidades de manifestação, os processos mais abrangentes de superação do Estado desenvolvimentista.

Embora este Estado viesse se desgastando material e politicamente desde os anos 70, ele entra em desagregação apenas no início da década de 80, particularmente em $1983^{4}$. Ocorre aí uma crise essencialmente política, mesmo que ela tenha sido precipitada pela insolvência decorrente do crescimento desmesurado da dívida externa e tenha se materializado como "crise fiscal". Com efeito, foi uma crise de hegemonia, em que - como ocorre em rupturas deste tipo - os representantes, os que seguravam o leme do Estado, dissociaramse dos representados, que se fracionaram e polarizaram em torno de interesses e idéias distintos. Fraturaram-se, por uma parte, as articulações típicas entre o Estado (e suas empresas), os capitais privados locais e o capital internacional, entre o setor público e o privado. Por outra parte, foi posta em xeque a estrutura existente de agregação e intermediação de interesses econômico-sociais em face do poder estatal. E os vários segmentos sociais que compunham a velha aliança desenvolvimentista magnetizaram-se por diferentes "fórmulas" de enfrentamento da crise econômica, fórmulas que oscilaram ideologicamente entre o nacionalismo desenvolvimentista e o neoliberalismo.

Essas rachaduras nas vigas de sustentação do velho Estado impulsionaram a derrocada do regime militar-autoritário. Contudo, a crise de hegemonia e a instabilidade econômica permaneceram irresolvidas ao longo da década de 80 e nos primeiros anos da de 90 . Em primeiro lugar, porque as dificuldades internacionais agravaram-se no período. O investimento externo, componente essencial do padrão brasileiro de desenvolvimento, converteu-se na década de 80 em desinvestimento. Não só os empréstimos privados estrangeiros cessaram como ocorreu, ao longo desses anos, uma enorme transferência líquida de recursos para o exterior, principalmente em função do serviço da dívida externa.
${ }^{3}$ Cf., sobre a Era Vargas, Barboza Filho (1995).

${ }^{4}$ Encontra-se uma análise dessa crise de Estado e seus desdobramentos até a eleição de Fernando Collor em Sallum Jr. (1996). 
Encontra-se descrição detalhada da organização e atividades das novas associações em Freifuss (1989) e em Diniz (1993).

6 Está fora dos propósitos deste artigo discutir as origens das idéias liberais que acabaram por se difundir no seio do empresariado brasileiro. Mas vale lembrar que sua reorientação ideológica, embora seja elemento-chave para explicar a emergência de um novo bloco político hegemônico no país, constitui parte da expansão mundial das idéias econômicas liberais. Esta expansão ocorre com vigor a partir do final dos anos 70, quando os governos Ronald Reagan nos EUA e Margareth Thatcher na Inglaterra passam a lhes dar peso nas respectivas políticas domésticas e no plano internacional. É claro que os constrangimentos políticos e econômicos internacionais e as situações internas afetaram muito o quando e o ritmo em que aquelas idéias se difundiram e foram reelaboradas em cada país. Para uma discussão abrangente do tema cf. Biersteker (1995).
Além disso, desde a segunda metade da década, acentuaram-se as pressões políticas norte-americanas em prol da "liberalização econômica". Em segundo lugar, aumentou muito a presença no espaço público nacional de movimentos sociais, organizações populares, de classe média e, mesmo, de empresários que - além de impulsionarem a consolidação da democracia política - reduziram drasticamente o raio de manobra que tinham os dirigentes do Estado para definir saídas para a crise "de cima para baixo".

Apesar dessas circunstâncias - completamente distintas das existentes até os anos 70 - tentou-se resolver problemas derivados da crise do Estado Desenvolvimentista dentro de seu antigo quadro de referência. Buscou-se recuperar autoridade do governo sobre o Estado e deste sobre a sociedade como se o Estado já não tivesse perdido grande parte de sua autoridade política e sua força material. Em razão disso os ensaios ortodoxos e heterodoxos de enfrentamento da crise econômica - desencadeados no governo Sarney e no período Collor defrontaram-se com o veto e/ou a adesão reticente dos componentes da antiga aliança desenvolvimentista, "aliança" que se manteve no poder, mesmo depois da crise de 1983, embora frouxamente alinhavada e sem direção definida.

Apenas por volta de 1986/1988 é que, em meio à desagregação da herança varguista, os participantes do antigo pacto nacional-desenvolvimentista começam a reorientar-se politicamente.

As classes proprietárias e empresariais, como reação às iniciativas reformistas do governo na Nova República e, principalmente, ao Plano Cruzado, passaram a mobilizar-se e a organizar-se de forma autônoma visando conformar a ação e as estruturas estatais. Com o fim do regime militar-autoritário, pareceu que o corporativismo, os "anéis burocráticos" e os "cartórios" deixaram de ser suficientes como garantias do controle exercido pelo empresariado sobre o Estado. Não apenas o empresariado renova e multiplica suas organizações e expande sua atuação na esfera pública ${ }^{5}$ mas também a sua perspectiva passa a predominar largamente nos meios de comunicação de massa, difundindo-se, com isso, na massa empresarial e nas classes médias.

O importante é que esta atuação desenvolta não se orientava para o passado, para reconstituir o velho Estado e mesmo a sociedade autocrática que a alicerçava. No correr da década dos 80 foi tornando-se claro para o empresariado que a retomada do crescimento econômico e a redução das tensões sociais já não poderia depender da presença dominante do Estado no sistema produtivo. Pelo contrário, ela dependeria da ampliação do grau de associação da burguesia local com o capital estrangeiro e envolveria concessões liberalizantes em relação ao padrão de desenvolvimento anterior. Agora, o empresariado combate o intervencionismo estatal, clama por desregulamentação, por uma melhor acolhida ao capital estrangeiro, por privatizações, etc. Em suma, passa a ter uma orientação cada vez mais desestatizante e internacionalizante ${ }^{6}$.

Apesar desta guinada político-ideológica do empresariado ter parecido avassaladora, especialmente pelo domínio que tinha da mídia, seu resultado de curto prazo foi modesto. Em primeiro lugar, ela encontrou resistências entre os assalariados organizados. Provocou no pessoal do Estado, especialmente das 
empresas estatais, antigos aliados do pacto nacional-desenvolvimentista, um movimento ideológico de sentido oposto, de defesa do "nacional" e do "estatal", identificados em geral com os partidos de "centro esquerda" e "de esquerda". Acrescente-se que, a partir do reconhecimento do direito de sindicalização dos funcionários públicos pela Constituição de 1988, dezenas e, depois, centenas de organizações formadas por eles ingressaram na Central Única dos Trabalhadores reforçando sua orientação estatista e nacionalista.

Em segundo lugar, as organizações empresariais não conseguiram converter seu crescimento sociopolítico em força político-institucional. Foram derrotadas no Congresso Constituinte com a ampliação das limitações ao capital estrangeiro, com o aumento do controle estatal sobre o mercado em geral e com a multiplicação dos mecanismos de proteção social aos funcionários, trabalhadores, aposentados e assim por diante. De fato, apesar de decadente, o modelo nacional-desenvolvimentista - é verdade que permeado por conquistas democratizantes - foi juridicamente consolidado através da Constituição de 1988. Criou-se uma carapaça legal rígida, aparentemente poderosa, que assegurava a preservação das velhas formas de articulação entre Estado e mercado no exato momento em que o processo de transnacionalização e a ideologia neoliberal estavam para ganhar, de fato, uma dimensão mundial com o colapso dos socialismos de Estado, cujo eixo era a União Soviética.

Aconstitucionalização parcial da "era Vargas" deu-lhe uma sobrevida, em meio à mudança na correlação de forças econômicas e sociais no plano nacional e internacional. Mas fez da Constituição de 1988 um alvo de ataque de médio e longo prazo $^{7}$ das elites empresariais e de seus porta-vozes intelectuais e políticos e, inversamente, trincheira de defesa das organizações operárias, de funcionários públicos, de empregados da empresas do Estado e da classe média assalariada, especialmente da ligada aos serviços públicos.

As eleições presidenciais de 1989 radicalizaram as polarizações político-ideológicas entre Estado/mercado, internacional/nacional e adicionaram a estes pares opostos a contraposição de modalidades distintas de democracia, a democracia política numa versão delegativa e outra numa versão mais participativa, ao estilo social-democrata ${ }^{8}$. Apesar da vitória de Fernando Collor-porta-voz do anti-estatismo, do ingresso do país no Primeiro Mundo (pela modernização tecnoeconômica) e de uma visão shumpeteriana de democracia - a enorme votação de Luiz Inácio da Silva mostrou como tinha força popular seu projeto de desenvolvimentismo democratizado e distributivista e, ao revés, como penetrara pouco na sociedade o projeto liberal-internacionalizante do empresariado.

De qualquer maneira, mesmo por vias transversas, o governo Collor (março de 1990 a setembro de 1992) contribuiu para danificar o arcabouço institucional nacional-desenvolvimentista e para reorientar em um sentido antiestatal e internacionalizante a sociedade brasileira. Eisso tanto no plano das regras e normas articuladoras de Estado e mercado como no plano da difusão ideológica.

Foram suspensas as barreiras não-tarifárias às compras do exterior e implementou-se um programa de redução progressiva das tarifas de importação ao longo de quatro anos ${ }^{9}$. Ao mesmo tempo, implantou-se um programa
${ }^{7}$ Digo alvo de médio e longo prazo porque a instabilidade da moeda e a forma de combatêla tornaram-se cada vez mais as questões políticas centrais da sociedade brasileira.

8 A contraposição entre essas versões de democracia inspira-se na distinção feita por Luiz Werneck Viana, a propósito dos projetos de Lula e Collor e depois de Lula e Fernando Henrique, entre democracia política e democracia social, esta sendo entendida como a absorção no plano político do processo de democratização da sociedade (cf. Viana, 1995). 
9 As tarifas alfandegárias médias passaram de $31,6 \%$ em 1989 para $30,0 \%$ em setembro de 1990, 23,3\% em 1991, $19,2 \%$ em janeiro de 1992, 15,0\% em outubro de 1992 e $13,2 \%$ em julho de 1993, seis meses antes que o cronograma inicialmente fixado.

${ }^{10}$ Apesar da redução das barreiras às importações, o fracasso dos programas de estabilização lançados a partir do início do governo Collor (exceção feita ao Plano Real), a recessão vigente na maior parte do período e a preservação de uma política cambial favorável às exportações e prejudicial às importações desestimularam novos investimentos industriais e restringiram a concorrência dos produtos estrangeiros. Por isso, o impacto das medidas liberalizantes sobre a estrutura do parque industrial brasileiro foi diminuto. Além disso, a indústria doméstica encontrou no Mercosul uma válvula de escape à recessão interna e às dificuldades de competir no plano mundial.

11 Referimo-nos aqui ao cesarismo, fenômeno político em que, numa situação de crise, o entrechoque de forças políticas eqüipotentes permite o surgimento de um líder providen- de desregulamentação das atividades econômicas e de privatização de empresas estatais (não protegida pela Constituição) para recuperar as finanças públicas e reduzir aos poucos o seu papel na impulsão da indústria doméstica. Finalmente, a política de integração regional materializada na constituição do Mercosul (1991) tinha como horizonte ampliar o mercado para a produção doméstica dos países-membros.

Com isso, desistia-se de construir no país uma estrutura industrial completa e integrada, em que o Estado cumpria o papel de redoma protetora em relação à competição externa e de alavanca do desenvolvimento industrial e da empresa privada nacional. De um ponto de vista positivo, definiu-se com as medidas tomadas uma estratégia de integração competitiva da economia doméstica ao sistema econômico mundial. Esperava-se preservar apenas aqueles ramos industriais que conseguissem, depois de um período de adaptação, mostrar suficiente vitalidade para competir abertamente numa economia internacionalizada. Dessa forma, o parque industrial doméstico tendia a converter-se em parte especializada de um sistema industrial transnacional ${ }^{10}$.

Esta reorientação estratégica constituiu inflexão importante na nossa transição política, pois produziu alterações institucionais que incorporavam no plano do Estado mudanças político-ideológicas que já vinham ocorrendo no seio do empresariado e das camadas médias. No entanto, embora sintonizada doutrinariamente com o empresariado local e o transnacional, a inflexão liberal não foi suficiente para soldar um novo pacto que superasse a crise de hegemonia instaurada em 1983. É que embora à primeira vista Collor parecesse e, mesmo, quisesse apresentar-se como um César providencial, saído das fendas da ordem política em crise para superá-la, o seu governo, ao invés, contribuiu para aumentar drasticamente as incertezas, quebrando completamente as expectativas das forças políticas em disputa. Recorde-se a promessa de Collor de deixar a direita furiosa e a esquerda perplexa. Sem dúvida cumpriu a promessa, atacando as classes proprietárias muito além do que Lula ousaria.

Com efeito, para estabilizar a moeda, o Plano Collor colocou em xeque a segurança jurídica da propriedade privada: além de retomar o congelamento de preços, seqüestrou e reduziu parte dos haveres financeiros do empresariado e da classe média. O governo, ademais, sujeitou as organizações tradicionais de representação empresarial a ataques verbais sistemáticos e articulou, em paralelo, grupos de empresários para lhe dessem suporte na implementação de sua política de desenvolvimento. Pretendeu exercer o poder dissociado da classe política e seus mecanismos tradicionais de sobrevivência. Reduziu as despesas do Estado desorganizando a administração pública com dispensas arbitrárias e em massa de funcionários. Tentou fragilizar as organizações operárias que se lhe opunham incentivando organizações alternativas ligadas ao governo.

Em suma, Collor no governo fracassou como César ${ }^{11}$, tornou-se agente de aprofundamento da crise política. Ao invés de oferecer às forças em disputa meios para saírem de modo consentido dos seus impasses, tentou impor-lhes uma alternativa "de cima para baixo". Tentou restaurar autocraticamente a estabilidade da moeda, base das relações de troca e da autoridade do 
Estado sobre o mercado, numa sociedade que, embora mal alinhavada politicamente, havia avançado muito no caminho da democratização.

A mudança nas condições do mercado internacional de capitais, $o$ legado de Collor (positivo e negativo), a exacerbação da instabilidade político-econômica no período Itamar Franco e o crescimento avassalador do prestígio popular do candidato das esquerdas à Presidência da República constituíram condições e alavancas poderosas para a tentativa seguinte, efetivada em 1994, de "costurar" a superação da crise de hegemonia que corroía a sociedade brasileira desde o início dos anos $80^{12}$.

Recordemos rapidamente as novas condições a que se fez referência. Em primeiro lugar, o reinício do afluxo de capitais para a América Latina, como muitos já sublinharam, mudou completamente as condições para o exercício de políticas de estabilização pois a precariedade das reservas internacionais tinha sido uma severa restrição às políticas anti-inflacionárias desde os anos $80^{13}$.

Quanto à herança do período Fernando Collor, há dois aspectos a salientar. Mesmo com a repulsa que culminou no processo de impeachment, preservou-se - a despeito das objeções do presidente Itamar Franco - a estratégia liberal que se começara a implementar em 1990 (abertura comercial e privatizações). Isso sinaliza que, entre as forças político-partidárias majoritárias que sustentavam o governo Itamar, o reformismo liberal já avançara tanto que inviabilizava qualquer volta ao nacionalismo desenvolvimentista. Ademais, depois dos experimentos heterodoxos de Collor, tornou-se muito arriscadotanto do ponto de vista político quanto em função da eventual reação do Judiciário - quebrar a indexação pelo controle ou congelamento de preços ou quaisquer medidas legislativas de duvidoso valor jurídico. Se estas novas condições restringiam o campo das possibilidades de desenhar uma "saída para a crise", o crescimento do prestígio popular das oposições, impulsionado pela instabilidade política e econômica do período Itamar, recomendava às forças governistas não só eliminarem a causa do crescimento do adversário mas união para enfrentálo, sob pena de naufragarem como no final da Nova República.

Essas condições e alavancas deram especificidade à fortuna encontrada por algumas lideranças políticas que, bem situadas no seio do Estado, tiveram virtu suficiente para negociar a associação entre partidos de centro e direita em torno da continuidade das reformas liberais, da estabilização da economia e da tomada do poder político central, corporificando tudo isso no lançamento bem sucedido do Plano Real e na candidatura, afinal vitoriosa, à Presidência da República do seu articulador, o então Ministro da Fazenda Fernando Henrique Cardoso.

Esta referência ao encontro entre fortuna e virtu retoma, de modo um pouco diverso, a idéia de "momento maquiaveliano", de Pocock, usada por Lourdes Sola e Eduardo Kugelmas para enfatizar a atuação das lideranças na reconstrução do Estado, na mesma situação histórica ${ }^{14}$. Eles lembram que nas conjunturas críticas é central a capacidade das lideranças de aproveitarem ou não "as janelas de oportunidade (no plano internacional, por exemplo) graças à recombinação de algumas das propriedades (genéticas) das instituições dadas cial, que constrói a ponte política para um novo tipo de Estado em que as forças em luta possam conviver (cesarismo progressivo) ou, pelo contrário, é o elo de ligação entre a situação catastrófica e uma forma política antiga, já ultrapassada (cesarismo regressivo). O autor chave a este respeito é Antônio Gramsci. O emprego que aqui se faz é algo metafórico. Para um balanço curto, mas rico, dos significados do termo na literatura especializada, cf. o verbete "Cesarismo" em Bobbio (1994).

${ }^{12}$ Utilizo-me abundantemente da análise das condições econômicas e políticas que cercaram a elaboração do Plano Real que se encontra em Sola \& Kugelmas (1996).

${ }^{13} \mathrm{O}$ afluxo de capitais começou a atingir o Brasil em 1991 intensificando-se a partir de 1992, o que permitiu acumular reservas de divisas consideráveis - de algo como 9 bilhões em fins de 1991, passou-se a quase 24 bilhões em 1992 para atingir cerca de 42 bilhões em meados de 1994.

${ }^{14}$ Estes autores transferem para a experiência brasileira a idéia de Pocock (1975) utilizada por Malloy \& Connaghan (1996), na análise dos países dos Andes Centrais. 
no sistema político e econômico brasileiro; uma recombinação que justifica o uso da categoria de statecraft porque determinada pela prevalência do interesse geral da comunidade política - e da ordem política - ameaçadas pelo confronto entre interesses particularistas"(Sola \& Kugelmas, 1996, p. 404).

Segundo este raciocínio, a utilização criativa da revisão constitucional para gerar condições fiscais mínimas para a estabilização (o Fundo Social de Emergência, votado pelo Congresso em fevereiro de 1994); a instituição de uma moeda paralela, a URV, unidade de conta (cujo valor em Cruzeiros Reais era fixado diariamente) que não quebrou a indexação mas a exacerbou, gerando por alguns meses uma espécie de "hiperinflação de laboratório"; e a substituição da URV pelo Real em 01/07/1994, ancorado no dólar, mas não igual a ele; tudo isso, em suma, além de dezenas de regulamentações específicas, teria produzido a estabilidade. Por essa via se teria assegurado "um princípio de universalidade-incorporado em instituições e práticas - sobreposto à particularidade e à contingência inerentes ao comportamento descontrolado das forças contendoras", para usar as palavras de Malloy e Connaghan sobre o momento maquiaveliano.

Em relação a isso haveria que fazer alguns poucos reparos. Em primeiro lugar, esse princípio de universalidade que se sobrepõe aos particularismos, esse interesse geral que está na base da construção ou reconstrução do Estadoé ele próprio, e estou seguro que os autores o reconheceriam, um particular que ganha foros de universal porque se torna hegemônico. O momento maquiaveliano em questão foi passo decisivo na superação de uma crise de hegemonia, na definição de um novo sistema estável de poder para sociedade brasileira. Segundo, o papel das lideranças, a virtu, teve menos latitude do que supõem Sola e Kugelmas. Com efeito, o que se efetiva em 1994 dá apenas a amarração final em alicerces que vinham sendo socialmente construídos, como se mostrou, desde o Plano Cruzado. Terceiro, mesmo que o Plano Real tenha sido uma formula técnica brilhante de converter uma "hiperinflação surda" em estabilidade monetária, ele foi apenas um instrumento essencial mas subordinado do "momento maquiaveliano". O essencial deste estava na composição política entre a direita e o centro político-partidário em torno de um projeto de conquista e reconstrução do poder de Estado segundo uma ótica predominantemente liberal. Não fora assim, como entender que o Congresso Nacional tenha transferido, ainda em fevereiro de 1994, recursos fiscais importantes dos estados e municípios para a União (com a criação do Fundo Social de Emergência), para sustentar um programa de estabilização a ser implantado pelo ministro da Fazenda-e possível candidato à Presidência - quando todos os partidos disputavam as governanças estaduais e, portanto, poderiam ser prejudicados pela decisão?

O extraordinário sucesso do Plano Real, a eleição de Fernando Henrique Cardoso para a Presidência já no primeiro turno, a escolha de um Congresso Nacional em que a coalizão partidária vitoriosa tinha folgada maioria, a vitória de aliados políticos do presidente da República nos pleitos para as governanças de quase todos os estados - tudo isso anunciava que, em $1^{\circ}$ de janeiro de 1995, assumiriam o leme de um Estado, já ancorado numa moeda com boas chances de manter-se estável, representantes de um novo sistema de poder hegemônico, pron- 
tos para completar a tarefa de moldar a sociedade às suas diretrizes.

A ênfase dada ao momento maquiaveliano na reconstrução do Estado, complementa e reforça o papel cumprido pelo conceito de hegemonia. Os dois sublinham a insuficiência do conhecimento das estruturas para a explicação dos processos políticos, especialmente em situações de crise; uma classe dominante não se transforma em dirigente a menos que consiga organizar-se e universalize os seus interesses na sociedade; e isso não ocorre a menos que lideranças políticas encontrem uma "fórmula política" que permita a adesão da maioria das forças políticas em presença.

Um bom mapa estrutural permite perceber, por exemplo, que toda a "janela de oportunidade" tem seu preço. Assim, a volta das aplicações de capital estrangeiro ao país permitiu acumular reservas em divisas que puderam ser aproveitadas para "ancorar" o Real, mas a estabilidade da nova moeda ficou na dependência de sua recriação constante e, portanto, em parte, da "boa vontade" do sistema financeiro internacional e das empresas multinacionais. Um mapa desse tipoé insuficiente, porém, porque não permite deduzir de forma fundamentada, por exemplo, que meios serão escolhidos para a recriação das reservas necessárias à estabilidade monetária, escolha essa que afeta o grau e a forma da referida dependência. A menos, é claro, que se acredite que só há uma maneira de fazê-lo. Mas isso seria cair no discurso oficial que tende a justificar suas escolhas como "inevitáveis"15.

\section{Liberalismo, Estabilização e Desenvolvimento}

Mesmo do ângulo específico que se explora aqui, não há forma simples de caracterizar o primeiro governo de Fernando Henrique Cardoso. De uma perspectiva econômica e sóciopolítica, sua gestão forma uma unidade que cobre um período superior ao do mandato oficial. Começa de fato no lançamento do Plano Real, antes pois da posse oficial do Presidente, e termina já no seu segundo governo, no dia 15 de janeiro de 1999, quando se alterou radicalmente o regime cambial do país.

Durante todo este período, o governo Cardoso buscou com perseverança cumprir o propósito de liquidar os remanescentes da Era Vargas, pautando-se por um ideário multifacetado, mas que tinha no liberalismo econômico sua característica mais forte. Salvo engano, o núcleo dessa perspectiva pode ser resumido neste pequeno conjunto de proposições: o Estado não cumpriria funções empresariais, que seriam transferidas para a iniciativa privada; suas finanças deveriam ser equilibradas e os estímulos diretos dados às empresas privadas seriam parcimoniosos; não poderia mais sustentar privilégios para categorias de funcionários; em lugar das funções empresariais, deveria desenvolver mais intensamente políticas sociais; e o país teria que ampliar sua integração com o exterior, mas com prioridade para o aprofundamento e expansão do Mercosul ${ }^{16}$.

Este ideário liberal básico materializou-se em iniciativas que mudaram institucional e patrimonialmente a relação entre Estado e mercado. Seu alvo central foi quebrar alguns dos alicerces legais do Estado nacional-desenvolvimentista, parte dos quais fora constitucionalizado em 1988. Ou seja, visaram reduzir a par-
${ }^{15}$ Encontram-se na p. 126 do artigo de Nobre \& Freire (1998) ótimas observações sobre a produção oficial do "inevitável".

16 A estratégia de aprofundar o Mercosul indica quão moderado era o liberalismo que perpassava o novo bloco hegemônico. Pelo menos desde 1993, o Mercosul deixou de ser visto apenas como bloco comercial. Desde então o Brasil buscou integrar-se regionalmente também do ponto de vista energético e industrial. Além disso, a política brasileira tem como horizonte a integração da América do Sul. Cf., a respeito, Sallum Jr. (1997). 
ticipação estatal nas atividades econômicas e dar tratamento igual às empresas de capital nacional e estrangeiro. O governo Cardoso conseguiu isso através da aprovação quase integral de projetos de reforma constitucional e infra-constitucional que submeteu ao Congresso Nacional. Os mais relevantes foram: a) o fim da discriminação constitucional em relação a empresas de capital estrangeiro; b) a transferência para a União do monopólio da exploração, refino e transporte de petróleo e gás, antes detido pela PETROBRÁS, que se tornou concessionária do Estado (com pequenas regalias em relação a outras concessionárias privadas); c) a autorização para o Estado conceder o direito de exploração de todos os serviços de telecomunicações (telefone fixo e móvel, exploração de satélites, etc.) a empresas privadas (antes empresas públicas tinham o monopólio das concessões).

Além de desencadear este conjunto de reformas constitucionais, o governo Fernando Henrique estimulou fortemente o Congresso a aprovar lei complementar regulando as concessões de serviços públicos para a iniciativa privada, já autorizadas pela Constituição (eletricidade, rodovias, ferrovias, etc.), conseguiu a aprovação de uma lei de proteção à propriedade industrial e aos direitos autorais nos moldes recomendados pelo GATT e preservou o programa de abertura comercial que já havia sido implementado. Sustentado pela legislação que permitia e regulava a venda de empresas estatais desde o período Collor e pelas reformas constitucionais promovidas desde 1995, executou um enorme programa de privatizações e de venda de concessões tanto no âmbito federal como no estadual.

Este conjunto de iniciativas parece ter materializado o código comum do novo bloco hegemônico - grande maioria dos parlamentares, burocratas e dirigentes do Executivo, empresariado de todos os segmentos, mídia, etc. - com larga penetração na classe média e em parte do sindicalismo urbano e na massa da população. Com efeito, as medidas legislativas foram aprovadas com facilidade pelo Congresso Nacional, apesar da oposição da minoria de esquerda posicionada atrás das bandeiras da defesa do "patrimônio público" e da "economia nacional". E as privatizações e vendas de concessões foram realizadas com grande sucesso e apoio popular, a despeito das escaramuças jurídicas promovidas pelas organizações de esquerda e seus simpatizantes.

Contudo, para além do código que dava um mínimo de unidade de crença e propósito ao novo bloco político hegemônico, houve fortes polarizações no seu interior, polarizações que se materializaram em uma disputa interna sempre renovada em torno da política econômica e em certa duplicidade e hibridismo das próprias ações do Estado em relação à economia.

O exame destas disputas político-ideológicas no interior do novo bloco político hegemônico e das ações do governo torna perceptível a existência de uma polarização básica entre duas versões distintas de liberalismo uma mais doutrinária e fundamentalista, o neoliberalismo e outra, que absorve parte da tradição anterior, o liberal-desenvolvimentismo. A primeira versão foi sem dúvida a predominante, orientando de modo consistente o núcleo duro da política econômica governamental. A segunda versão de liberalismo não teve a consistência da primeira, não se materializou em texto programático e nem chegou a orientar sistematicamente a ação governamental (cf. Sallum 
Jr., 1998, p. 63-115; p.157-199) ${ }^{17}$. Mas pode ser reconstruída a partir do debate público, de conceitos esparsos aparecidos em documentos oficiais e do "espírito" de iniciativas governamentais surgidas em reação a certas consequiências sociais e econômicas supostamente negativas da ortodoxia liberal.

Para a corrente neoliberal dominante a prioridade era a estabilização rápida dos preços por meio das seguintes medidas complementares: a) manutenção do câmbio sobrevalorizado frente ao dólar e outras moedas ${ }^{18}$, de forma a estabilizar os preços internos e pressioná-los para baixo pelo estímulo à concorrência derivada do barateamento das importações; b) preservação e, se possível, ampliação, da "abertura comercial" para reforçar o papel do câmbio apreciado na redução dos preços das importações; c) o barateamento das divisas e a abertura comercial permitiriam a renovação rápida do parque industrial instalado e maior competitividade nas exportações; d) política de juros altos, tanto para atrair capital estrangeiro - que mantivesse um bom nível de reservas cambiais e financiasse o déficit nas transações do Brasil com o exterior, como para reduzir o nível de atividade econômica interna - evitando assim que o crescimento das importações provocasse maior desequilíbrio nas contas externas; e) realização de um ajuste fiscal progressivo, de médio prazo, baseado na recuperação da carga tributária, no controle progressivo de gastos públicos e em reformas estruturais (previdência, administrativa e tributária) que equilibrassem "em definitivo" as contas públicas; f) não oferecer estímulos diretos à atividades econômicas específicas, o que significa condenar as políticas industriais setoriais e, quando muito, permitir estímulos horizontais à atividade econômica - exportações, pequenas empresas, etc., devendo o Estado concentrar-se na preservação da concorrência, através da regulação e fiscalização das atividades produtivas, principalmente dos serviços públicos (mas não estatais) ${ }^{19}$.

Entre o lançamento do Plano Real e março de 1995, essa perspectiva fundamentalista dominou plenamente a política econômica. Deixou-se o real valorizar até quase 0,80 por dólar, estancando de forma dramática a inflação, o que aumentou extraordinariamente a renda disponível e a demanda das camadas mais pobres da população. Com isso, apesar dos juros altos, a economia - que já vinha aquecida desde o começo do governo Itamar Franco - apresentou um boom extraordinário, amplificando a demanda por importações e tornando-se um desaguadouro mais fácil para produtos usualmente exportados. Ademais, com o objetivo declarado de evitar que a demanda maior resultasse em acréscimos de preços, decidiuse em agosto-setembro reduzir as tarifas alfandegárias em relação aos países do Mercosul, antecipando a tarifa externa comum, a ser implantada apenas em janeiro de 1995. Isso tudo levou à reversão dos saldos no comércio exterior brasileiro, positivos desde 1987. Já em novembro de 1994 os déficits comerciais começaram a aparecer, chegando em dezembro a mais de 1 bilhão de dólares.

Do ângulo do fundamentalismo liberal, o desequilíbrio externo não constituía grande problema. Como o essencial era chegar o mais rapidamente à estabilidade dos preços, era preciso manter apreciada a taxa de câmbio por um longo período e reduzir, com importações, o poder dos oligopólios industriais fixarem preços. Eventuais déficits no comércio e nos serviços com o
${ }^{17}$ No texto citado, caracterizo o liberaldesenvolvimentismo de forma diversa, como uma estratégia em construção. O texto foi escrito em julho de 1997 e havia sinais que permitiam essa interpretação do processo.

${ }^{18}$ A sobrevalorização cambial não é inerente à perspectiva neoliberal. Pelo contrário, esta orienta-se por um câmbio "de mercado". A versão abrasileirada de neoliberalismo, que dominou a política econômica, via na sobrevalorização um meio eficaz de obrigar as empresas nacionais a buscar rapidamente padrões internacionais de eficiência sob pena de saírem do mercado. Esta versão é fundamentalista no sentido de que se constitui numa política de conversão forçada dos que não se enquadram. Sobre o neoliberalismo, cf. Unger (1998). A respeito da apreciação cambial e sua quantificação, cf. Schwartsman (1999).

${ }^{19}$ Essa perspectiva neoliberal teve como representantes políticointelectuais característicos: no governo, o expresidente do Banco Central, Gustavo Franco, o ex-secretário de Política Econômica Winston Fritsch e o ministro da Fazenda Pedro Malan; fora do governo, suas expressões mais notórias foram alguns economistas da PUC-Rio, dentre os quais Rogério Werneck e Marcelo de Paiva Abreu. 
${ }^{20}$ Em março de 1995, o Banco Central criou um sistema de bandas - tetos máximo e mínimo - de variação cambial, provocando uma desvalorização do real em relação ao dólar de $6,0 \%$. A partir daí e ao longo de 1996 o BC promoveu minidesvalorizações cambiais seguindo aproximadamente a variação dos preços do atacado. Desde o final de 1996, com a perspectiva da produção de um déficit acentuado na balança comercial, inicia-se um processo de desvalorização em relação ao dólar mais intenso do que a inflação doméstica. Todas essas alterações, porém, não foram reconhecidas como políticas. Só a partir da crise asiática, em 1998, o governo admite que sua política cambial envolvia uma desvalorização real de 7,5\% anuais em relação à moeda norteamericana. exterior poderiam ser cobertos pelas reservas de divisas disponíveis e pelo afluxo de capitais externos. Acreditava-se que o ambiente de estabilidade criado pelo Plano Real e taxas elevadas de juros atrairiam parte da enorme massa de capitais disponíveis no mercado mundial. E que, aos poucos, o sistema econômico se ajustaria em bases mais produtivas, de forma a ter uma inserção mais equilibrada no mercado mundial, o que reduziria a necessidade de poupança externa para "fechar" o balanço de pagamentos.

Obviamente, constitui pressuposto dessa política neoliberal de estabilização uma visão extremamente otimista do mercado financeiro mundial e da rapidez com que o "ajuste fiscal" se tornaria a nova âncora do real, em lugar do dólar.

A crise mexicana de dezembro de 1994 sinalizou os riscos implícitos na adoção de uma política macroeconômica orientada pelo fundamentalismo liberal. Quer dizer: dependendo das circunstâncias internacionais, um desequilíbrio acentuado da balança comercial e de serviços poderia encontrar dificuldades de ser financiado por capitais externos. No caso em pauta, as reservas internacionais caíram de mais de 41 bilhões de dólares, em outubro de 1994, para 31,4 bilhões em junho de 1995, tendo-se reduzido 1,2 bilhões apenas entre fevereiro e março.

Além disso, a enorme apreciação cambial apontou para a possibilidade de desindustrialização parcial do país pois, para as multinacionais de alguns setores (como as do setor automotivo), importar foi se tornando mais vantajoso do que produzir internamente, e porque ficou cada vez mais difícil para as empresas locais competir com os importados sem aumentar as compras de matérias primas e componentes no Exterior.

Frente às consequiências real ou potencialmente negativas do fundamentalismo liberal, desde março de 1995 até o final de 1998, o governo passou a tomar medidas compensatórias, tais como: criação do sistema de bandas cambiais móveis, desvalorização nominal e depois real, embora suave, do câmbio $^{20}$, aumento de tarifas alfandegárias para alguns produtos industriais, política industrial para o setor automotivo, ampliação extraordinária do volume de empréstimos pelo sistema do Banco Nacional de Desenvolvimento Econômico e Social com taxas especiais de juros (taxas de longo prazo), programação de investimentos em parceria com a iniciativa privada para a recuperação da infra-estrutura econômica do país (Programa Brasil em Ação), programas de estímulo à exportação, seja por isenção de impostos para produtos agrícolas, seja por financiamento a juros subsidiados, renegociação das dívidas agrícolas, programas especiais de financiamento para setores industriais selecionados, de financiamento para pequenas e médias empresas e assim por diante.

Não cabe aqui analisar cada uma dessas iniciativas, mas a maioria delas contribuiu para a preservação e reestruturação do sistema econômico nacional e de vários setores específicos, inclusive tradicionais (como o setor de têxteis e de calçados). O que importa é que a maioria dessas medidas teve como fonte de inspiração aquilo que denominamos antes liberal-desenvolvimentismo. Nele, o velho desenvolvimentismo dos anos 50 a 70 renasce sob predomínio liberal. Nessa versão de liberalismo também dá-se prioridade à estabilização monetária, mas 
a urgência com que ela é perseguida aparece condicionada aos efeitos potenciais destrutivos que as políticas antiinflacionárias ocasionarão no sistema produtivo. Por isso, combate-se o radicalismo dos fundamentalistas, exigindo-se um câmbio não apreciado, para evitar déficits na balança de transações correntes (comercial e de serviços), e juros mais baixos para não desestimular a produção e o investimento. De outra forma: a combinação de câmbio menos valorizado e juros "razoáveis" não permitiria uma queda tão brusca da inflação, mas provocaria menos desequilíbrios da economia doméstica em relação ao exterior e, assim, menor dependência de aportes de capitais estrangeiros para equilibrar o balanço de pagamentos. Este desenvolvimentismo continua industrializante, mas seu foco ampliou-se para incluir as atividades produtivas em geral, desde a agricultura até os serviços. Além disso, os seus partidários não aspiram, como desejavam seus antecessores dos anos 50, construir no país um sistema industrial integrado. Aspiram, sim, que a produção local tenha uma participação significativa no sistema econômico mundial. No entanto, esse desenvolvimentismo limitado pelo molde liberal apenas vê com bons olhos formas bem delimitadas de intervenção do Estado no sistema produtivo. Assim, dentro dessa perspectiva, são favorecidas as políticas industriais setoriais, mas desde que limitadas no tempo e parcimoniosas nos subsídios. Tais políticas terão por objetivo não a substituição de importações a qualquer preço mas o aumento da competitividade setorial e, quando muito, o "adensamento das cadeias produtivas" para desenvolver no país o máximo possível de atividades econômicas com padrão internacional de produtividade ${ }^{21}$.

Não obstante certa flexibilização da política cambial e a adoção paulatina de medidas "compensatórias" sob a inspiração liberal-desenvolvimentista, o fundamentalismo liberal continuou sendo o eixo da política econômica. Quer dizer, embora o ajuste fiscal "definitivo" fosse sendo sempre postergado ao longo do governo FHC (em função das dificuldades e interesses políticos imediatos do governo federal), valorização cambial e juros elevados foram convertidos em instrumentos permanentes de estabilização.

Este conjunto de políticas e/ou de ausência de políticas governamentais provocou uma distribuição de recursos econômicos que alterou decisivamente, em relação ao passado, as posições relativas dos vários segmentos socioeconômicos que estão na base do novo bloco hegemônico ${ }^{22}$. É o que se verá esquematicamente na seqüência.

Em primeiro lugar, o predomínio neoliberal na política macroeconômica fragilizou dramaticamente a economia nacional em relação ao sistema financeiro mundial. É certo que a política macroeconômica não produziu o resultado sozinha. Somaram-se a ela, para desequilibrar as trocas da economia com o exterior, os muitos anos de relativa estagnação econômica e instabilidade monetária e a abertura comercial. De qualquer modo, esse desequilíbrio crônico ampliou o grau de dependência da economia nacional em relação ao sistema financeiro mundial pois ela passou a demandar volumoso ingresso líquido de capitais estrangeiros para equilibrar o Balanço de Pagamentos.

Vejamos isso mais de perto. Em situações em que as relações entre uma economia nacional e o sistema financeiro mundial são normais, o grau de
${ }^{21}$ Dentro do governo incluem-se nesta perspectiva, dentre outros, o ministros José Serra, Luiz Carlos Mendonça de Barros e Luiz Carlos Bresser Pereira e o Secretário de Política Econômica e, depois, da CAMEX, José Roberto Mendonça de Barros. Fora do governo alinhamse uma enorme quantidade de economistas, tendo à frente Antônio Delfim Neto, jornalistas econômicos, como Luiz Nassif e Celso Pinto, etc.

${ }^{22}$ Produzem-se efeitos também sobre os dominados, mas não podemos tratar disso aqui. 
Fragilidade Financeira Externa e Saldo da Balança Comercial

${ }^{23} \mathrm{O}$ conceito de fragilidade financeira origina-se em H. Minsky tendo sido reelaborado e adaptado para a economia brasileira por Paula \& Alves Jr. (1999, p. 79).

${ }^{24}$ No artigo antes citado encontra-se análise econômica da evolução da fragilidade durante o Plano Real e também explicações quanto aos cálculos dos índices a partir dos dados do Balanço de Pagamentos do Banco Central.

25 A política de desaquecimento adotada depois da crise mexicana provocou, segundo o CNI, um ano de redução dos índices de produção industrial (abril de 1995 a março de 1996), sendo que fragilidade financeira externa se altera conforme forem as necessidades que a economia considerada tenha de recorrer ao mercado financeiro internacional para cobrir seu déficit externo corrente e as dívidas que estão vencendo ${ }^{23}$. Quanto mais ela tem de obter recursos externos para equilibrar suas contas, mais uma mudança nas condições do mercado internacional de capitais tornase capaz de afetar os fluxos de financiamento para o país, sujeitando a moeda nacional ao perigo de eventuais ataques especulativos tendentes a desvalorizála. O gráfico abaixo indica a evolução da fragilidade financeira externa brasileira entre 1992 e 1997, cotejando-a com a curva que mostra o comportamento negativo da balança comercial no mesmo período ${ }^{24}$.

saldo comercial

indice de

(U\$ 1,000.00)

fragilização

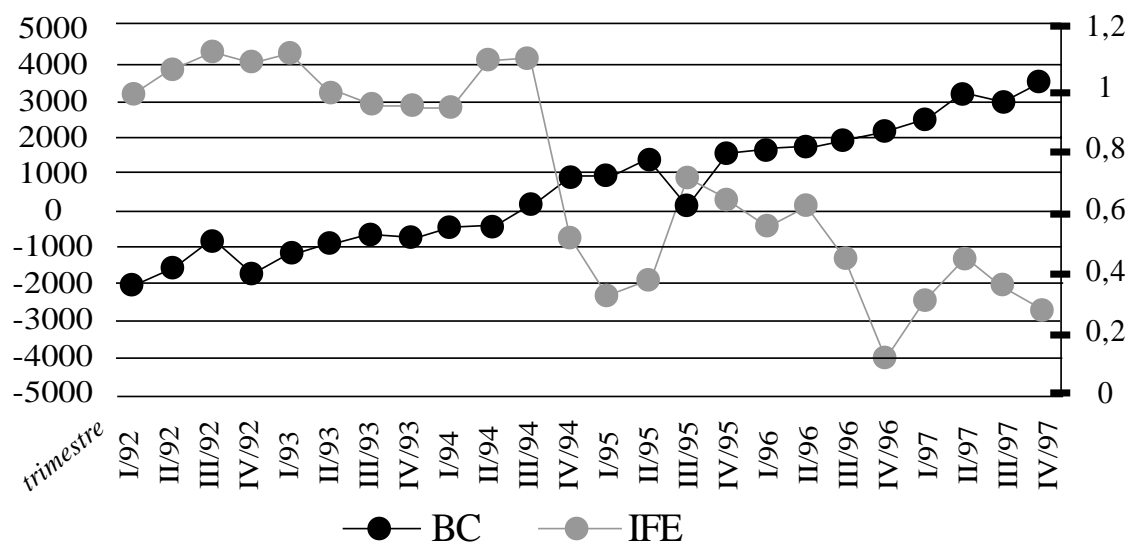

A crise mexicana do fim de 1994, a crise asiática de 1997 e a moratória da Rússia, de agosto de 1998, deram lugar a ataques especulativos do tipo mencionado. Em todas as situações críticas, o Brasil perdeu grande quantidade de reservas internacionais e o governo reagiu de forma similar: manteve a estabilidade da moeda, elevando drasticamente os juros para preservar reservas, para restringir a atividade econômica interna e o desequilíbrio externo ${ }^{25}$.

É verdade que, em função dos choques externos, se adotaram cada vez mais enfaticamente as políticas "compensatórias" antes mencionadas, inclusive uma leve desvalorização real da taxa cambial. Mas elas não foram suficientes para contrabalançar a fragilidade financeira externa, especialmente à medida que a situação internacional tornou-se bem mais instável do que na época do lançamento do Plano Real. O resultado é conhecido: crises sucessivas até o "ataque" final contra o real, já no início do segundo mandato de Fernando Henrique Cardoso, que acabou provocando a mudança completa do regime de câmbio (para câmbio flutuante) e a conseqüente desvalorização do real em cerca de $50 \%$ até o fim de janeiro de 1999.

Em segundo lugar, a estratégia de estabilização privilegiou a esfera financeira vis-a-vis as atividades de produção/comercialização de bens e serviços. Assim, apesar da redução do peso das instituições financeiras no PIB, as políticas monetária e cambial têm funcionado permanentemente como bombas de sucção 
de rendimentos dos segmentos econômicos da órbita real e do Estado para o conjunto dos detentores de títulos financeiros, tanto estrangeiros como locais.

Dentro desse quadro geral, sublinhe-se que a política de contenção permanente das atividades econômicas traduziu-se em baixas taxas de crescimento do produto e, a partir de 1997, em altos índices de desemprego ${ }^{26}$. Desta forma, embora a estabilização da moeda tenha provocado, de início, ganhos reais para as camadas assalariadas menos privilegiadas, a continuidade da política de câmbio apreciado e juros altos vem produzindo, desde 1996, uma regressão naquele processo e uma acentuada transferência de renda para os detentores de haveres financeiros.

Outro ponto a sublinhar é que a perpetuação das políticas cambial e monetária como substitutivo do ajuste fiscal acabou por elevar sistematicamente o endividamento público, principalmente em relação a credores inter$\operatorname{nos}^{27}$, de tal forma que no último ano do primeiro governo Cardoso o pagamento de juros passou a ser o principal fator explicativo do crescimento do déficit público, maior que o déficit da previdência pública e privada (cf. Schwartsman, 1999, p. 20-21). Isso significa que, mesmo quando alterados os parâmetros básicos da política econômica, a dívida pública demandará que continue a haver transferências muito elevadas de recursos do conjunto da sociedade para o Estado, de modo que este possa satisfazer os seus credores.

Sublinhe-se que, caso houvesse predominado na política econômica a ala liberal-desenvolvimentista do bloco hegemônico, o impacto sobre as frações socioeconômicas teria sido completamente distinto. É muito provável que a inflação não tivesse caído tão drasticamente, mas em compensação não teriam sido tão privilegiados os rendimentos financeiros vis-a-vis os derivados das atividades produtivas e do trabalho. Por isso, há que reexaminar interpretações que vêem o governo FHC como expressão da conquista do poder político pela burguesia paulista ou que afirmam que, desde as eleições de 1994, os "paulistas" estariam no poder ${ }^{28}$. Vale lembrar que o empresariado industrial paulista manifestou-se várias vezes contra a política econômica do governo Fernando Henrique e que esta foi comandada por economistas oriundos da Pontifícia Universidade Católica do Rio de Janeiro e sintonizada com a ortodoxia liberal lá dominante. Com efeito, a argumentação desenvolvida até aqui, sublinha que, ao invés de manter afinidades com a burguesia paulista ou mesmo uma modernidade abstrata de mercado representada pelos paulistas, o governo Fernando Henrique tendeu a se sintonizar com as orientações daquilo que Chesnais denomina capitalismo mundial financeirizado (cf. Chesnais, 1998a; 1998b). E o fez, apesar da resistência que havia dentro do governo, fora dele mas no interior do novo bloco hegemônico e no conjunto das forças políticas contrárias ao novo bloco hegemônico.

Em terceiro lugar, o Estado reorientou suas políticas em relação aos setores socioeconômicos. O mais importante e mais óbvio: as empresas estatais deixaram de ser os pilares da política estatal. Não só elas vêm sendo privatizadas com rapidez, mas setores que antes eram atendidos por serviços da administração direta têm sido entregues ao cuidado de empresas privadas. O exemplo mais entre agosto de 95 a março de 96 os índices caíram abaixo de zero. A partir de abril desse ano notou-se uma recuperação ainda hesitante das atividades industriais. No primeiro semestre de 97 houve recuperação nítida, o que levou a um déficit grande na balança de comércio exterior daquele ano. Com a explosão da crise asiática no fim de 97 o Banco Central voltou a elevar drasticamente os juros, desaquecendo novamente as atividades econômicas.

${ }^{26}$ Segundo o IBGE, no período pós-REAL (de 01/07/1994 em diante) as taxas de crescimento do PIB e as taxas médias anuais de desemprego aberto (30 dias) foram, respectivamente, de $7,81 \%$ e $4,84 \%$ em 94-95, de $0,45 \%$ e $5,75 \%$ em $95-96$, de $5,39 \%$ e $5,77 \%$ em 96-97, de $1,41 \%$ e $7,37 \%$ em $97-98$ e de $-0,67 \%$ e $8,32 \%$ em 98-99. As taxas de crescimento do PIB partem da base zero. As taxas médias anuais de desemprego foram cedidas gentilmente por Alvaro Comin.

27 Entre dezembro de 1994 e julho de 1998 a Dívida Líquida Total do setor público passou de $28,1 \%$ para $38,6 \%$ do PIB (36,3\% apenas para os credores internos) (cf. Schwartsman, 1999, p. 21). 
${ }^{28}$ Refiro-me aqui, respectivamente, aos sob outros aspectos excelentes trabalhos de Viana (1995) e de Barboza Filho (1995).

${ }^{29} \mathrm{O}$ indicador mais geral desta mudança é o crescimento muito lento do peso dos investimentos no PIB comparado com o aumento extraordinário dos investimentos diretos estrangeiros no país (o Brasil tornou-se o segundo destino mais importante entre os países "emergentes"). gritante aqui é o das estradas de rodagem, cuja manutenção ou construção tem sido concedida a empresas privadas em troca da exploração dos serviços que prestam - pedágio e arrendamento dos terrenos públicos que as margeiam. Esta redução das funções empresariais do Estado não eliminou mas tem transformado profundamente o intervencionismo estatal. Ele vem expandindo suas funções normativas e de controle - seguindo o modelo da agência reguladora de telecomunicações (Anatel) - e preserva grande parte da sua capacidade de moldar as atividades econômicas por meio das compras de bens e serviços.

A empresa privada nacional também deixou de ser o foco privilegiado das políticas do Estado. Se o Estado conserva o seu viés industrializante, como se viu, até agora não há indicação nem de intenção governamental nem de reivindicação empresarial de desenvolver uma indústria propriamente nacional. Pelo contrário, além das empresas estrangeiras terem sido equiparadas constitucionalmente às nacionais, a orientação básica do Estado tem sido a de atrair ao máximo os investimentos estrangeiros e promover sua associação com empresas nacionais. Entre as associações empresariais a reivindicação não é privilegiar as empresas nacionais mas reduzir as suas desvantagens competitivas, pela equalização das condições - tributárias, de juros, de infra-estrutura, etc. - de que dispõem as estrangeiras.

Mesmo o sistema de financiamento estatal foi moldado por esta orientação, no mínimo "equalizadora". Na verdade, esta mudança teve início no governo Collor. Já então o BNDES foi autorizado a financiar empresas estrangeiras desde que captasse recursos externos e, com autorização da Presidência de República, mesmo sem este tipo de recursos. Quando o governo tratava de tornar atraente o setor de telecomunicações para investimentos estrangeiros, em 1997, a Presidência da República, através de medida provisória, autorizou empréstimos dos bancos oficiais a empresas de capital estrangeiro em setores considerados prioritários, como o de telecomunicações, independentemente da fonte de recursos.

O governo FHC fez, no entanto, mais do que "equalizar" as condições entre empresas estrangeiras e nacionais. A política de estabilização (juros altos/câmbio apreciado) por si só desvalorizou as empresas locais porque contribuiu para descapitalizá-las e favoreceu as empresas multinacionais, na medida em que dispõem de alternativas de financiamento fora do Brasil, além de outras vantagens que o tamanho e a presença em vários mercados lhes dão. Além disso, o Estado (nos níveis federal e estadual) procurou atrair sistematicamente empresas multinacionais para dois setores-chave da indústria, o automotivo e o de telecomunicações, não só modulando a legislação tributária e o sistema de financiamento mas também através de "convites" e outras iniciativas destinadas a "vender" o Brasil como destino prioritário de investimentos para o capital estrangeiro. Este conjunto de incentivos implícitos e explícitos certamente contribuiu para o substancial aumento verificado na participação nos principais mercados das empresas de capital estrangeiro visa-vis às de capital nacional ${ }^{29}$.

Ademais, desapareceu - ou quase - a prioridade que o nacional- 
desenvolvimentismo dava à indústria. No âmbito do BNDES, principal agente financeiro da industrialização do país, foi notável a diversificação setorial das empresas atendidas. Além da indústria, passou-se também a financiar atividades comerciais (centros de compras), turísticas (parques de diversão), agrícolas, etc.

Em contrapartida, a agricultura empresarial ganhou uma inusitada preeminência na gestão econômica do governo Fernando Henrique. Além de medidas que beneficiaram diretamente o $\operatorname{setor}^{30}$, as autoridades governamentais deram-se conta de que a agricultura brasileira - nas novas circunstâncias, de concorrência internacional mais aberta - tem uma grande capacidade de competição, mesmo sob condições adversas (infra-estrutura, financiamento e câmbio). Por isso, o setor tornou-se objeto de especial preocupação do governo também no plano internacional. A partir de 1996 e, especialmente, em 1997 - por ocasião das discussões sobre a Associação de Livre Comércio das Américas (ALCA) e sobre um acordo de livre comércio com a União Européia - as questões agrícolas e o combate ao protecionismo norte-americano e europeu ganharam posição central na diplomacia brasileira.

As mudanças havidas nas diretrizes de exercício do poder não foram tão drásticas a ponto de romper um parâmetro básico da aliança nacionaldesenvolvimentista, a intocabilidade da propriedade agrária. É verdade que a própria estabilização monetária reduziu drasticamente valor da propriedade territorial enquanto a fonte de apropriação de riqueza ao desvalorizar a terra em cerca de $45 \%$ (em média). Mas, além disso, por iniciativa própria e por pressão social (do Movimento dos Sem-Terra [MST], Confederações Nacional dos Trabalhadores na Agricultura [CONTAG] e da Igreja), o governo desenvolveu ao longo de quatro anos um extenso programa de reforma agrária. Este programa envolveu não apenas um grande número de desapropriações e de assentamen$\operatorname{tos}^{31}$. Ademais, promoveu-se um conjunto de reformas institucionais que visavam ampliar a taxação sobre a terra improdutiva e aumentar o poder de intervenção do poder público na estrutura fundiária. Modificou-se em 1996 o sistema de tributação do Imposto Territorial Rural introduzindo-se sobretaxas para terras improdutivas (a maior delas é de $20 \%$ do valor da terra improdutiva para propriedades com mais de 5000 hectares e menos de $30 \%$ de utilização) e estipulou-se que o valor da terra nua seria declarado pelo proprietário e serviria como valor máximo para efeitos de desapropriação. Instituiu-se também o rito sumário nas desapropriações de terras dificultando para os proprietários de terras improdutivos o uso de medidas protelatórias.

Não cabe subestimar estas iniciativas. No entanto, os seus efeitos estiveram longe de corresponder às expectativas iniciais. Em primeiro lugar, a arrecadação do ITR não apresentou alterações substanciais (o que já seria de esperar pela facilidade com que foi aprovado pela "bancada ruralista") e, em segundo lugar, os assentamentos efetuados concentram-se mais nas regiões de ocupação recente do que nas antigas ${ }^{32}$. Isso indica a grande capacidade de resistência da velha estrutura agrária e de seus representantes, mesmo quando não contam com o respaldo do poder Executivo e encontram poucos porta-vozes explícitos.
${ }^{30}$ Foram renegociadas as dívidas dos agricultores - deu-se carência, os prazos foram alongados e os juros reduzidos. Com isso, abriuse a oportunidade para novos investimentos. Foi criada uma linha de crédito muito favorecido para a agricultura familiar, o PRONAF. Os planos de safra passaram a ser divulgados a tempo, antes das decisões de plantio. Foi reformado o sistema de seguro agrícola, beneficiando os agricultores obedientes ao zoneamento do Ministério da Agricultura. Isentou-se de ICMS as exportações agrícolas e os equipamentos destinados à agricultura. Em lugar da política de preços mínimos, foram criados instrumentos financeiros para aumentar a segurança de comercialização da safra. Boa parte das obras de infraestrutura do programa "Brasil em Ação" destinaram-se a melhorar o escoamento dos produtos agrícolas (cf. Mendonça de Barros, 1998).

${ }^{31}$ No período de 1965 a 1984 , foram assentadas cerca de 208.889 famílias, as quais receberam em média 135 ha. Entre 1985 e 1994 , foram assentadas 206.650 famílias, recebendo em média 54 ha. Entre 1995 e 1997, 193.667 famílias receberam 44 ha em média (cf. Tavares dos Santos, 1998). 


\section{Estratégia Política e Gestão Econômica}

A exposição anterior, apesar de tocar apenas em alguns aspectos da política governamental, indica claramente que, ao longo do primeiro mandato de Fernando Henrique Cardoso, o governo contribuiu para ocorressem enormes mudanças no sistema socioeconômico nacional e nas suas relações com o Exterior. Entretanto, apesar dessas alterações e/ou por causa delas, alguns dos seus principais alvos originais não foram atingidos.

Com efeito, passados quase cinco anos desde o lançamento do Plano Real, o governo Cardoso não conseguiu produzir contas públicas estruturalmente equilibradas, que pudessem ancorar a moeda nacional em lugar do dólar. Colheu esse resultado sem desvio significativo em relação ao

32 A repartição por grandes regiões, entre 1988 e 1997, mostra uma concentração de famílias assentadas no Norte $(38 \%)$ e no Nordeste $(36 \%)$, totalizando $74 \%$ dos assentamentos no Brasil. Este padrão se mantém nos últimos três anos (19951997), pois embora o Nordeste passe a liderar o processo, com $40 \%$ das famílias assentadas, o Norte, com $32 \%$ e o Centro-Oeste, com $19 \%$, totalizam 51 $\%$ das famílias assentadas (cf. Tavares dos Santos, 1998).

${ }^{33}$ Depois da quebra do regime cambial e da introdução do câmbio flutuante, a estabilidade tem sido mantida graças a um ajuste-fiscal-conjunturale-repressivo e à política monetária.

${ }^{34}$ Em 17 de julho de 1996, um ano e meio depois de começar a tramitar o projeto de reforma da previdência, chave do "ajuste fiscal", o governo sofreu várias derrotas importantes na Câmara dos Deputados quando da votação do projeto em $2^{\circ}$ turno. A ponto de se dar ao senador Beni Veras a missão de "recompô-lo" no Senado, neoliberalismo abrasileirado que, desde o Plano Real, dominou a administração da política monetária e cambial, mesmo que alguns dos seus custos se tornassem cada vez mais evidentes - crescimento medíocre, privilegiamento dos rendimentos financeiros, desnacionalização da economia, intercâmbio cronicamente deficitário com o Exterior e, por fim, alto desemprego. $\mathrm{O}$ eixo da política macroeconômica foi mantido, mesmo em meio à instabilidade financeira mundial reinante de 1997 em diante, até que o governo viu-se na contingência de romper o próprio regime cambial vigente - apesar do respaldo que tinha do FMI e dos países do G 7 - como último recurso contra o "ataque especulativo" (fuga de divisas) ocorrido na virada dos anos 1998/199933.

Como explicar a insistência nessa política macroeconômica se, pelo menos desde meados de $1996^{34}$, já era sabido com bastante segurança que dificilmente se chegaria ao fim do governo Fernando Henrique com finanças públicas estruturalmente equilibradas? De fato, a expectativa de demora era tão grande que, nesta época, já se ensaiava justificar a necessidade de reeleição do presidente da República justamente para que se pudesse ter tempo de completar as "reformas estruturais". Qual a razão, então, de o governo optar reiteradamente por uma política econômica tendente a produzir custos sociais internos e de riscos financeiros externos muito maiores do que uma alternativa de tipo liberal-desenvolvimentista?

Não creio que se encontre uma resposta convincente para essas questões na discussão econômica das alternativas que se apresentavam. Mesmo que o debate econômico tenha sido, e seja, essencial para identificar as implicações socioeconômicas prováveis das opções governamentais, minha hipótese é que a escolha feita em prol do fundamentalismo liberal tem uma explicação principalmente política. Certamente, não foi uma escolha simples, tomada de uma vez por todas. A questão apresentou-se várias vezes durante o mandato de FHC e mesmo antes dele (quando da crise mexicana, por exemplo). Infelizmente não há condições, nos limites deste artigo, de examinar o problema nas conjunturas que se apresentou. Tentar-se-á, de todo modo, identificar os principais parâmetros das decisões políticas tomadas.

Creio que a hipótese mais consistente para explicar a opção governamental é bastante simples: a manutenção do fundamentalismo neoliberal 
foi interpretado pela Presidência da República como um meio decisivo para assegurar o necessário controle sobre o sistema político, tendo em vista realizar a pesadíssima agenda de reformas institucionais que constituía o núcleo duro do programa do governo.

Explico-me. O objetivo central do programa de governo de Fernando Henrique era preservar a estabilidade monetária e mudar o padrão de desenvolvimento brasileiro, superando a Era Vargas, que - nas palavras do Presidente - "ainda atravanca o presente e retarda o avanço da sociedade". Já que ela fora parcialmente constitucionalizada em 1988, o cerne do programa do novo governo consistia em um conjunto de projetos destinados a reformar parte da Constituição e alterar leis infra-constitucionais que materializavam institucionalmente o remanescente do varguismo.

Como as reformas constitucionais programadas eram numerosas e de aprovação muito difícil (uma mudança constitucional exige 3/5 de votos nominais em dois turnos de votação em cada uma das casas do Congresso Nacional), o governo dedicou a maior parte das suas energias à luta na arena político-institucional ${ }^{35}$. Ora, nessa arena, a coalizão vitoriosa em 1994 contou, desde o seu início, com uma posição política excepcional para realizar seus propósitos. O pleito resultou não apenas na vitória da candidatura de Fernando Henrique Cardoso, mas também numa boa maioria no Congresso Nacional para a coligação partidária de centro-direita que se articulou em torno dele (PSDB-PFL-PTB). Além disso, nos principais estados da Federação venceram as eleições candidatos a governador aliados do presidente. Ademais, a escolha do ministério permitiu ao presidente eleito consolidar sua maioria parlamentar, incorporando à coalizão original o maior partido brasileiro, o PMDB, cujo candidato à Presidência havia sido fragorosamente derrotado. Em boa parte das votações, além disso, a coligação governista podia contar com a maioria dos votos do PPB, partido situado à direita da aliança governista. Em contrapartida, as forças de esquerda - marcadas pelo nacionalismo e pelo estatismo, orientadas para a reconstrução do projeto nacionaldesenvolvimentista numa versão favorável à incorporação das massas populares - conseguiram obter só uma presença frágil no mundo político oficial, cerca de 1/5 das cadeiras da Câmara dos Deputados e menos ainda do Senado. Elegeram alguns governadores, mas estes acabaram mostrando-se favoráveis ao projeto de reforma do Estado defendido por Cardoso. Em suma, na arena institucional, a coligação político-partidária afinada com a orientação política do presidente da República, além de dominar o Executivo federal, dominava claramente o Legislativo e tinha grande presença na Federação.

Contudo, uma afinidade de orientação político-ideológica entre Executivo e sua base parlamentar não costuma converter-se automaticamente em votos favoráveis às propostas governamentais. No sistema político brasileiro, essa conversão está usualmente associada, tanto à distribuição para a base parlamentar de recursos políticos específicos, controlados pelo Executivo e por seu "dispositivo" de apoio no Congresso, como ao "prestígio político" do governo e do Presidente, isto é, à aprovação difusa que eles têm da para que pudesse recomeçar do zero na Câmara. Além da lentidão e diluição da reforma da previdência, também davam motivos para pessimismo quanto ao "ajuste fiscal" as dificuldades de avançar na reforma administrativa e os grandes aumentos de despesas públicas ocorridas por reajustes salariais concedidos, em 1994, por Itamar Franco e vários governadores de Estado em final de mandato.

35 Distinguem-se aqui três arenas de disputa do poder, segundo os diferentes tipos de recursos políticos utilizados: a arena institucional - onde os atores usam os recursos derivados das posições institucionais que ocupam; a arena da influência, em que os atores competem entre si usando como recursos sua capacidade de convencimento (espaço na mídia, lideranças locais, etc.); e a arena de coerção, em que os atores políticos usam meios físicos para conseguir seus objetivos (greves, passeatas, lockout, forças para-militares, etc.). A distinção foi proposta em Flanagan (1973). 
${ }^{36}$ Argelina C. Figueiredo e Fernando Limongi têm acentuado em vários artigos a força dos controle político do Executivo e de seu "dispositivo partidário" sobre a base parlamentar no interior do Congresso Nacional. Eles mostram força até na aprovação de matérias impopulares como a reforma da previdência (cf. Figueiredo \& Limongi, 1998).

${ }^{37}$ A paralisação - que entre outras demandas exigia o cumprimento de promessas salariais feitas no período Itamar Franco durou cerca de dois meses. Ela tornou-se muito impopular porque, além da reivindicação de aumento de salários ter sido estigmatizada pelo discurso oficial como "exagerada" e "perigosa para o Plano Real", ocasionou falta de gás de cozinha e de combustíveis. Essa impopularidade abalou a unidade do movimento e facilitou sua derrota para o governo, cuja posição teve o suporte do Judiciário, que caracterizou a greve como ilegal. população ${ }^{36}$. Pode-se até dizer sem receio que quanto mais o governo dispõe de prestígio político, menos necessidade tem de recorrer à distribuição de recursos específicos, no estilo clientelista.

$\mathrm{Na}$ arena da influência, onde Fernando Henrique podia obter parte desse prestígio político para si e para seu programa, sua posição também era muito favorável. Os órgãos de comunicação de massa e a maioria dos "formadores de opinião" já aderira, há bastante tempo, à perspectiva mais liberal e internacionalizante que orientava o novo bloco hegemônico. Em especial, o próprio presidente da República era apresentado de forma extraordinariamente favorável: intelectual brilhante, com prestígio internacional; político afeito ao diálogo, reformista moderado, moralmente inatacável; e que, além de tudo isso, mostrara a rara capacidade de administrar com muita habilidade, em meio à turbulência econômica e política do governo Itamar Franco, um programa muito bem sucedido de estabilização. Contudo, a sintonia entre mídia e governo não é algo que se mantém "naturalmente", por inércia; depende, em parte, do grau em que a massa de consumidores das mídia mostra-se receptiva às políticas governamentais.

É claro que o domínio governamental numa das arenas serviu como reforço para controlar a outra. Contudo, o mais relevante é que tanto na arena institucional como na de influência a posição dominante do governo e do presidente foi sempre alicerçada na simpatia da grande maioria da população, sentimento derivado da estabilidade dos preços obtida com o Plano Real e da subseqüente melhora temporária das suas condições de vida. Explica-se: apesar de difuso, o prestígio popular tinha possibilidades de se converter, eventualmente, em formas específicas e variadas de apoio político ao governo - boa receptividade às suas mensagens ou impermeabilidade à opiniões contrárias a ele, disponibilidade para mobilizar-se em favor dele ou para votar em candidatos a ele associados e assim por diante.

Mesmo na arena coercitiva, onde a oposição dispunha de mais recursos, o referido sentimento difuso de simpatia popular teve relevância. Ele dificultou as mobilizações contrárias ao governo e facilitou o combate político às organizações de oposição que conseguiam ultrapassar aquela barreira.

Sublinhe-se, entretanto, que na arena coercitiva o efeito desmobilizador do prestígio popular difuso proveniente da estabilização teve apenas um papel suplementar. A própria estabilização quebrou o padrão costumeiro de luta distributiva, quer dizer, o estilo de mobilização e luta desenvolvido pelas organizações de assalariados para enfrentar o regime de inflação alta e indexada. Com isso, os resultados das mobilizações e paralisações tornaram-se mais incertos e as reivindicações mais difíceis de obter.

Ademais, o governo tratou de reduzir ao mínimo as possibilidades da oposição operar na arena coercitiva, tentando derrotar politicamente a Central Única dos Trabalhadores. Para isso adotou, já no primeiro semestre de 1995, uma posição não-negociadora e legalista para vencer a greve dos sindicatos de petroleiros ${ }^{37}$. Esperava quebrar, assim, a espinha dorsal do sindicalismo de oposição e debilitar um dos principais ícones do estatismo e do nacionalis- 
mo. É provável que tenha tido sucesso e que se possa atribuir à derrota dos petroleiros algo da debilidade apresentada pelo movimento sindical ao longo do governo Fernando Henrique.

A propósito da arena coercitiva, cabem duas pequenas mas importantes digressões. Em primeiro lugar, o governo Fernando Henrique não fez esforço para obter a contribuição positiva de organizações societárias para a execução de seu programa. Quer dizer, não apenas procurou desmobilizar a oposição mas desprezou a mobilização social em seu favor. Quase sempre procurou aprisionar a política nas arenas institucional e de influência ${ }^{38}$, isolando a política da sociedade organizada (cf. Oliveira, 1996, p. 59-60; p. 69).

Apesar disso - e este é outro ponto a sublinhar a propósito da arena coercitiva-o Movimento dos Sem-Terra (MST) manteve-se na ofensiva durante todo o governo Cardoso e com alto grau de apoio popular urbano. Fustigando o governo com invasões de terra e manifestações em todo o país, o MST obrigou a Presidência da República a transformar os órgãos dedicados ao tratamento da questão fundiária e a adotar medidas inovadoras para melhorar o seu programa de reforma agrária. O inegável sucesso desse movimento em prol de mais igualdade - mesmo sob as condições adversas que afetavam principalmente os atores coletivos enraizados nas classes populares - indica que o movimento de democratização da sociedade ainda continuará, por muito tempo, a ser uma das molas básicas da transformação da sociedade brasileira.

Este balanço esquemático da situação nas três arenas consideradas indica a enorme importância que tinha para o governo, e para a realização de seu programa, a manutenção do prestígio popular difuso produzido pela preservação da estabilidade de preços. Essa "simpatia" difundida no plano psicossocial dava ao governo bases sólidas para produzir resultados favoráveis nos vários campos de luta política.

Cabe tornar mais precisa esta proposição em dois sentidos. O primeiro deles é apenas uma reiteração. A ação política bem sucedida do governo nas várias arenas políticas teve no apoio difuso recebido da população apenas um dos seus componentes causais. Mesmo na arena políticoinstitucional, onde o governo Cardoso estava melhor posicionado, seu sucesso dependeu de outras condições tais como, do funcionamento dos sistemas de controle do "dispositivo governista" sobre sua base parlamentar, do conteúdo específico das medidas que pretendeu aprovar, etc.

O segundo é quase óbvio mas muito importante: a valorização da estabilidade monetária foi socialmente produzida. Ela não teria ocorrido caso a maior parte da população não tivesse sofrido a experiência traumática de alta inflação no período anterior ao Plano Real. Conseqüentemente, caso o status quo ante tivesse sido de estagnação econômica, baixa inflação e desemprego elevado, é provável que políticas orientadas para o crescimento rápido e o emprego teriam sido as de maior impacto popular.

A argumentação desenvolvida até aqui pretendeu sublinhar a lógica política que explica, em parte, a preferência pelo fundamentalismo neoliberal ao longo do primeiro governo Fernando Henrique. Essa escolha pode ter sido
${ }^{38}$ Foram exceções a mobilização e organização do empresariado agrícola junto ao Ministério da Agricultura no começo do governo e a tentativa de negociação com a CUT de um aspecto da reforma da previdência social. Sublinhe-se que, em ambos os casos, o rompimento do isolamento deu-se para melhorar uma posição governamental temporariamente desvantajosa na arena institucional. 
percebida pela Presidência da República como a forma mais segura de preservar a estabilidade dos preços, produzir prestígio político difuso para o governo e, conseqüentemente, maior controle sobre a atuação dos agentes e sobre os resultados obtidos nas várias arenas de disputa política.

Todavia, desvendar a determinação política da opção por uma alternativa de gestão econômica não significa transformá-la em algo inevitável. Ainda mais porque em cada momento em que a escolha foi reiterada não se decidiu entre políticas de objetivos antagônicos, como entre inflação versus estabilidade, ajuste ou desequilíbrio fiscal, etc. As alternativas que se ofereciam situavam-se no mesmo espectro político-ideológico, embora aí se localizassem em pólos opostos e cada uma delas produzisse, como já se enfatizou anteriormente, implicações socioeconômicas muito diferentes.

Para que se entenda melhor a lógica das escolhas feitas, vale montar uma pequena equação das implicações em custos/benefícios prováveis da escolha entre fundamentalismo neoliberal e liberal-desenvolvimentismo. $\mathrm{O}$ primeiro oferecia mais garantias imediatas de "segurar o Real" - preservando o prestígio político difuso que ajudava o governo a manter suas posições nas várias arenas políticas - e mais riscos de médio e longo prazo, por conta do eventual crescimento da taxa de desemprego e de perturbações provenientes do sistema financeiro internacional. $\mathrm{O}$ segundo prometia mais garantias de médio e longo prazo - maior impulso ao crescimento e ao equilíbrio das relações econômicas com o exterior e menor fragilidade em relação a oscilações bruscas do sistema financeiro internacional - porém menos segurança política de curto prazo, em função da eventual perturbação monetária derivada, por exemplo, de uma mudança na política cambial ou de juros.

É claro que, na avaliação de riscos, a sequiência temporal dos eventos altera o peso dos fatores a considerar. Ao longo do transcurso do primeiro governo Cardoso tornaram-se mais óbvios os ônus implícitos na gestão macroeconômica dominada pelo fundamentalismo neoliberal. Em compensação, a dinâmica dos eventos políticos que podiam colocar em xeque o domínio da coalizão governante e a liderança da Presidência da República sobre ela-eleições municipais, aprovação do direito de reeleição, nova eleição para cargos estaduais e federais, etc. - tendeu a acentuar os eventuais prejuízos políticos de uma mudança de política macroeconômica.

A perspectiva política de curto prazo, que parece ter dominado as opções do governo Fernando Henrique em política macroeconômica, não pode, entretanto, ser atribuída apenas ao resultado de cálculos políticos ad hoc, feitos a partir de uma equação mais ou menos complexa de custos e benefícios.

Diversamente, ela tem afinidade com uma certa concepção de exercício de democracia que marcou a estratégia política governamental ao longo do primeiro mandato presidencial de Fernando Henrique Cardoso. Trata-se de concepção de democracia representativa que não se abre - exceto excepcionalmente - à incorporação no espaço público de organizações sociais portadores de interesses coletivos. Com efeito, na elaboração de políticas públicas, o governo Fernando Henrique, ancorado no apoio difuso da população, res- 
tringiu a um mínimo sua articulação direta com grupos de interesse ou agrupamentos não-partidários de opinião. No exercício do poder, sua estratégia foi insular-se sistematicamente dos movimentos da sociedade organizada, concentrando seus esforços nas arenas institucional e de influência.

Desta forma, embora não haja como negar ao governo Fernando Henrique a qualificação de democrático e representativo, ele afastou-se de qualquer veleidade social-democrata. Pelo contrário, sua prática democrática foi de estilo delegativo. Não há que confundi-la, porém, com a concepção de democracia inerente ao programa de Collor, à medida que a delegação suposta no exercício de governo de Fernando Henrique não tem a marca personalista daquele.

\section{Considerações Finais}

Os acontecimentos de janeiro de 1999 quebraram, a despeito da vontade do governo Cardoso, as bases macroeconômicas que delimitaram o seu primeiro mandato presidencial. Em lugar do câmbio semi-fixo e sobrevalorizado, instituiu-se o câmbio flutuante e provavelmente subvalorizado, pelas circunstâncias desfavoráveis da mudança. Ao invés de uma política de juros altos, o Banco Central passou a orientar-se para a baixa dos juros até o patamar internacional, à medida que o controle da inflação assim o permitir.

O que se inaugurou, porém, com a crise econômico-financeira de janeiro não foi um processo de mudança para além dos limites do bloco hegemônico. Lançou-se, sim, em janeiro, as bases econômicas para uma possível transformação política no seu interior, em direção ao pólo liberal-desenvolvimentista.

No entanto, uma reversão desse tipo é extremamente problemática. E não me refiro aqui apenas às circunstâncias econômicas desfavoráveis em que se encontra o país, tanto no plano interno como no externo. O empobrecimento da população, a crise de janeiro e a elevação da inflação liquidaram o prestígio político difuso que sustentava boa parte do controle do governo sobre as várias arenas políticas. Apenas isso já tornaria a operação política muito mais difícil. Ademais, a insistência da Presidência na preservação do fundamentalismo liberal no primeiro mandato devorou parte dos quadros técnicos e dos apoios político-sociais que lhe permitiriam agora "virar o jogo". Por fim, ainda não está claro se o próprio presidente da República está convencido de que pode e deve transitar para a alternativa liberal-desenvolvimentista e para formas mais ativas de articulação do Estado com a sociedade organizada. Ainda mais porque estas alternativas, embora sintonizadas com o processo de democratização da sociedade que o país continua atravessando, envolvem grandes dificuldades políticas para sua implantação. 


\section{UNITERIS:}

State, government, political crises, political transition, hegemony, economical policy, development, neoliberalism, FHC.
SALLUM JR., Brasilio. Brazil under Cardoso: neoliberalism and developmentism. Tempo Social; Rev. Sociol. USP, S. Paulo, 11(2): 23-47, Oct. 1999 (edited Feb. 2000).

ABSTRACT: This article has got three parts. The first makes an exam of the processes of conquest of the power of the State, which culminated in the reelection of $\mathrm{FHC}$, using the concept of hegemony and the idea of Machiavellian moment derived from Pocock. The second part shows that the new political block in charge, besides its liberal and internationalizating orientation, polarizes itself between two opposed versions of liberalism, the neoliberal fundamentalism and the liberal-developmentism. It also discusses the social economical effects of the adoption of the neoliberalism by the government as an axe of its macroeconomic policy. The third part analyses the political reasons, which guided the presidency reiteratedly to this choice. The suggested hypothesis are that the Presidency of the Republic interpreted the maintenance of the neoliberal fundamentalism as a decisive way of assuring the necessary control over the political system. At the end it is suggested that the macroeconomical changes that started in January 1999 are the basis for a liberal-developmentist reorientation of the government.

\section{REFERÊNCIASBIBLIOGRÁFICAS}

Barboza Filho, Rubens. (1995) FHC: Os paulistas no poder. In: Amaral, Roberto (org.). FHC: Os paulistas no Poder. Niterói, Casa Jorge Editorial, p. 93-155.

Boвbio, Norberto et alli.(1994) Dicionário de Política. 6⿳a edição, Vol. 1. Brasília, Editora UnB .

Biersteker, Thomas J. (1995) The "triumph"of liberal economic ideias. In: Stallings, Barbara (org.). Global change, regional response. Cambridge, Cambridge University Press, p. 174-196.

Chesnais, François. (1998a) A fisionomia das crises no capitalismo mundializado. Novos Estudos, 52: 21-54, novembro.

(org.). (1998b) A mundialização financeira - gênese, custos e riscos. São Paulo, Xamã.

DinIz, Eli (org.). (1993) Empresários e Modernização Econômica: Brasil anos 90 . Florianópolis, Ed. UFSC/IDACON.

Figueiredo, Argelina C. \& Limongi, Fernando. (1998) Reforma da Previdência e Instituições Políticas. Novos Estudos, 51: 63-90, julho.

Fiori, José Luiz. (1995) Em Busca do Dissenso Perdido. Rio de Janeiro, Insight.

Flanagan, Scott. (1973) Models and methods of analysis. In: Almond, G. et alli (orgs.). Crisis, choice and change. Boston, Little Broen, p. 43-101.

FreIfuss, René. (1989) O Jogo da Direita - Na Nova República. Petrópolis, Vozes, p. 181-294. 
GARRETÓN, Manuel. (1993) Las transiciones en su contexto. In: Cambio XXI Fundación Mexicana (org.). Las transiciones a la democracia. Mexico, D.F., Miguel Porrua Ed.

Malloy, James \& Connaghan, C. (1996) Unsettling Statecraft, democracy and neo-liberalism in Central Andes. Pittsburg, Pittsburg University Press.

Mendonça de Barros, José Roberto (org.). (1998) Agricultura e Estabilização no Brasil (1995-1998). Brasília-DF, Embrapa-SPI/Ministério da Fazenda.

Nobre, Marcos \& Freire, Vinícius Torres. (1998) Política difícil, estabilização imperfeita: os anos FHC. Novos Estudos, 51: 123-147.

Oliveira, Francisco de. (1996) O primeiro ano do governo Fernando Henrique Cardoso (Debate). Novos Estudos, 44: 47-72, março.

Paula, Luiz Fernando Rodrigues de \& Alves Jr., Antônio José. (1999) Fragilidade financeira externa e os limites da política cambial no Real. Revista de Economia Política, 19(1): 72-93, janeiro-março.

Pocock, J.G.A. (1975) The Machiavellian Moment. Princeton, Princeton Univerty Press.

SAllum JR., Brasilio. (1996) Labirintos - Dos generais à Nova República. São Paulo, Hucitec/Sociologia-USP.

. (1997) Estamos reorganizando o capitalismo brasileiro (entrevista de Fernando Henrique Cardoso). Lua Nova, São Paulo, 39: 11-31.

(1998) Globalização e Estratégia para o Desenvolvimento: o Brasil nos anos 90. In: Dines, Alberto et alii. Sociedade e Estado: Superando Fronteiras. São Paulo, Edições Fundap, p. 243-280.

Schwartsman, Alexandre. (1999) A crise cambial e o ajuste fiscal. Revista de Economia Política, 19(1): 5-29, janeiro-março.

Sola, Lourdes \& Kugelmas, Eduardo. (1996) Statecraft, instabilidade econômica e incerteza política: o Brasil em perspectiva comparada. In: DinIz, Eli (org.). Anais do Seminário Internacional: O desafio da democracia na América Latina. Rio de Janeiro, Iuperj, p. 398-414.

Tavares dos Santos, José Vicente. (1998) Relatório Final do Projeto "Conflitos Sociais Agrários”. Convênio FAO-INCRA/IFLCHUFURGS, dezembro.

UnGER, Roberto Mangabeira. (1998) Democracy Realized -The progressive alternative. London/NewYork, Verso.

VIANA, Luiz Werneck. (1995) O Coroamento da Era Vargas e o Fim da História do Brasil. Dados, Rio de Janeiro, 38(1): 163-170. 